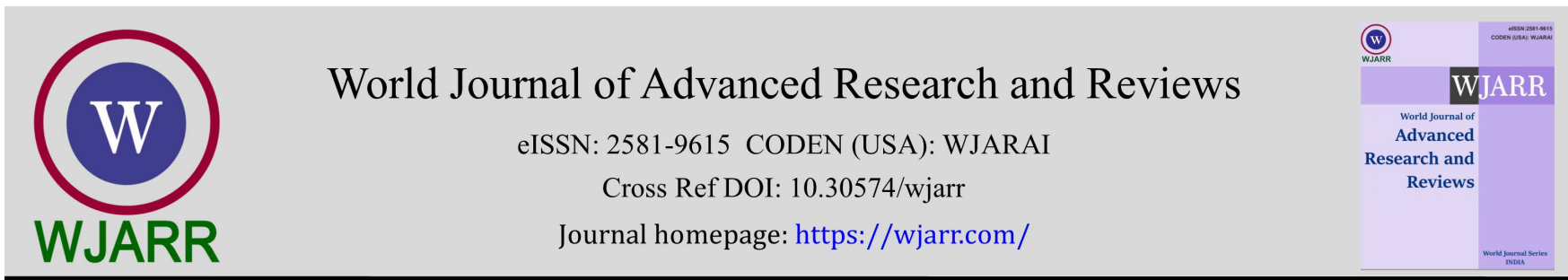

(CASE REPORT)

Check for updates

\title{
Successful spontaneous pregnancy in a nullipara with acquired gynaetresia: A case report
}

\author{
Nonye-Enyidah Esther Ijeoma * and Ohaka Henry Chinweowa \\ Department of Obstetrics and Gynaecology, Rivers State University Teaching Hospital, Port Harcourt, Rivers State, \\ Nigeria.
}

World Journal of Advanced Research and Reviews, 2021, 10(02), 157-160

Publication history: Received on 07 April 2021; revised on 09 May 2021; accepted on 12 May 2021

Article DOI: https://doi.org/10.30574/wjarr.2021.10.2.0220

\begin{abstract}
Background: Gynaetresia is the narrowing or complete occlusion of the vagina which may be congenital or acquired. Acquired gynaetresia is commoner in Nigeria due to female genital mutilation and vaginal insertion of herbs. Gynaetresia is a public health issue that requires a great attention to prevent all its associated morbidities.
\end{abstract}

Objective: To report a case of nullipara with acquired gynaetresia that presented in labour.

Methods: The case note of the patient and how she was managed were reviewed. Relevant review of the literature on the subject was also done.

Results: She was a 24 year old Primary Health Care (PHC) booked Gravida 3 Para $0^{+2}$, a trader with secondary level of education who presented in labour ward of Rivers State University Teaching Hospital (RSUTH) at an unknown gestation. She was referred from the PHC on account of labour pains of 6 hours duration and a dense fibrotic tissue sealing off most of the vaginal wall. There was a history of passage of herbal concoction in her vagina 14 months prior to presentation to induce abortion. She had emergency lower segment Caesarean Section (C/S) and outcome was a live male baby who weighed $3 \mathrm{~kg}$ with a good APGAR score. She did well post operatively, was counseled for vaginoplasty and discharged home with her baby on the $5^{\text {th }}$ post-operative day in good clinical state.

Conclusion: Acquired gynaetresia due to vaginal insertion of herbal pessaries is a preventable condition if only our women in this part of the world are made to understand the significance and implications of this act. This is by educating the public on the morbidities associated with this condition.

Keywords: Acquired gynaetresia; Vaginal herbs; Labour; Emergency caesarean section

\section{Introduction}

Acquired gynaetresia is commoner in developing countries like Nigeria while congenital ones are rare [1, 2]. The incidence in Nigeria is 7-8.5/1000 women [3]. Acquired gynaetresia in our environment is usually due to vaginal herbal insertion for the treatment of infertility, fibroids, utero-vaginal prolapsed and termination of pregnancy. It also results from female genital mutilation (FGM), vaginal birth injuries and repair of vesico-vaginal fistula. Insertion of herbs in the vagina for cosmetic purposes in order to bring the vaginal rugae back to how it was before delivery also results to gynaetresia [1-6]. In the developed countries, acquired gynaetresia is associated with chronic graft-versus-host reaction or following radiotherapy although congenital type is commoner $[5,6]$.

\footnotetext{
* Corresponding author: Nonye-Enyidah Esther Ijeoma

Department of Obstetrics and Gynaecology, Rivers State University Teaching Hospital.
} 
Trauma and infection of the genital tract lead to inflammation, adhesion and scarring of the vagina resulting in the atresia or stenosis of the vagina. In the immediate period, the patient experiences burning sensation and possibly a bleed. As healing occurs, the vagina may be completely occluded, resulting in secondary amenorrhoea, haematrometria, hematosalpinx and haematocolpos. It also causes dyspareunia and apareunia [7, 8]. All these complications will affect the women physically, psychologically, socially and financially. Therefore we report a rare case of spontaneous pregnancy that occurred through a pin hole in a thick fibrous tissue in the vagina. This was due to herbal concoction inserted into the vagina sometime ago to induce abortion.

\section{Case report}

Miss CJ was a 24 year old Primary Health Centre (PHC) booked G3P0 ${ }^{+2}$, a trader with secondary level of education. She presented to the labour ward unit of the hospital with a referral letter from the booked PHC on account of labour pains of 6 hours duration and a dense fibrous tissue sealing off the vagina leaving the vagina short at an unknown gestational age. There was no history of passage of show, drainage of liquor or bleeding per vaginam. There was history of superficial dyspareunia and difficulty with coital penetration of the vagina by her partner. She admitted having inserted herbs in her vagina in order to induce abortion 14 months prior to presentation. This resulted to pain and bleeding per vaginam which stopped after 5 days. Thereafter she noticed that her vagina had become smaller and the partner started to complain about it. She menstruated monthly and there was no history of dysmenorrhoea, oligomenorrhoea or cryptomenorrhoea. She has had 2 terminations of pregnancies (T.O.P) both at 8 weeks gestation. The first T.O.P was done using dilatation and curettage in a private clinic.

On Examination, she was in intermittent painful distress, not pale, anicteric, afebrile, not dehydrated and had no pitting pedal oedema. Her chest was clinically clear, pulse rate was $100 \mathrm{bpm}$ and blood pressure was $130 / 70 \mathrm{mmHg}$. Her abdomen was enlarged and fundal height was 36 weeks. She had three strong contractions in 10 minutes. There was a singleton fetus lying longitudinal with cephalic presentation, descent was four-fifths palpable and fetal heart rate was $144 \mathrm{bpm}$. The vulva was normal. There was a thick fibrous tissue midway into the vagina and the vaginal length was $4 \mathrm{~cm}$ from the introitus. Cervix was neither reached nor visualized. Urgent packed cell volume was $36 \%$, retroviral screening for HIV I \&II was sero-negative, urinalysis was normal. Urgent ultrasound scan done revealed a term pregnancy, a live male baby in cephalic presentation with heart rate of 148 beats $/ \mathrm{min}$.

A diagnosis of acquired gynaetresia secondary to chemical vaginitis in a nullipara in labour was made. She was counseled on the condition and the need for emergency caesarean section. She subsequently had emergency caesarean section and the outcome was a live male baby who weighed 3kg with a good APGAR score. Estimated blood loss was $400 \mathrm{mls}$. Post operatively, she was placed on nothing by mouth until reviewed. She received parenteral fluids, antibiotics and analgesia for 48 hours and was converted to oral antibiotics, analgesia and haematinics. Her packed cell volume on the second day after surgery was 34\%. Post operatively, it was noted that the vulval pad was always soaked with lochia. Another vaginal examination done revealed a pin hole to the left of the vagina that traversed through the thick fibrous tissue in the vagina that possibly connects the cervix to the vagina. She was counseled on the need for vaginoplasty with the plastic surgeons after the puerperal period.

She did well on antibiotics and analgesia and subsequently discharged home with her baby on the $5^{\text {th }}$ post-operative day with a two week appointment. She did not have any complaints during the two and six weeks' appointments but declined the proposed vaginoplasty.

\section{Discussion}

Acquired gynaetresia affected $15.4 \%$ of gynaecological cases done in a teaching hospital in Lagos, Nigeria over a period of 7 years [2]. Its peak incidence is among those aged 20-30 years [9]. Miss CJ was 24 years old.It affects tremendously the quality of life and reproductive career of the affected. The use of herbal concoction in the vagina results in chemical vaginitis and the vagina heals by fibrosis $[1,7]$. This is the commonest cause of acquired gynaetresia in developing countries like Nigeria where it is grossly under-reported and caused by untrained health workers and quacks $[1,2,7$, and 10]. Anzaku et al reported a similar case of acquired gynaetresia following the use of vaginal herbal insertion to induce abortion [7]. Kaur et al also reported a case of postpartum acquired gynaetresia from vaginal packing with clothes soaked in caustic soda [8].InArab countries,acquired gynaetresia results from daily vaginal insertion of rock salt post-partum to restore the vagina back to its former nulliparous rugae. This act can also result in vaginal infection, secondary amenorrhoea, dysmenorrhoea, haematocolpos and haematometria after healing by fibrosis [10]. 
Countries like Nigeria where harmful traditional and cultural practices like female genital mutilation and insertion of herbs in the vagina to cure a lot of ailments raise concerns regarding the safety of our women. Each year a good number of patients suffer avoidable injuries due to poverty, ignorance and poor quality of health care [11]. Also restrictive abortion laws in Nigeria push our women to harmful alternatives like our patient, a single lady and a petty trader resulted to using herbs in her vagina to induce abortion. This case is quite interesting because she spontaneously conceived through this pin hole in the vagina and carried the baby to term.

Treatment is mainly surgical ranging from simple excision to reconstructive vaginal surgery. Following a reconstructive surgery, a regular use of vaginal dilators, vibrators and molds aids in the success rate by reducing scarring and restenosis of the vagina $[12,13]$. Unfortunately, Miss CJ did not accept the vaginoplasty offered to her because she still menstruates even though the vagina is shortened by the adhesion. More so, she was able to conceive spontaneously with the condition.

\section{Conclusion}

Poverty and ignorance are still a huge problem in the developing countries. Government should help to improve on the restrictive abortion laws so that our women will stop patronizing quacks. Also harmful cultural practices should be abolished. Lastly health education will also go a long way to reduce maternal morbidities and mortalities associated with harmful practices in our society.

\section{Compliance with ethical standards}

\section{Acknowledgments}

We wish to express our profound gratitude to everybody who participated in the management of this patient.

\section{Disclosure of conflict of interest}

Authors have declared that no competing interests exist.

\section{Statement of informed consent}

As per university standard guideline, participant consent and ethical approval have been collected and preserved by the authors.

\section{References}

[1] Nakhal RS, Williams CE, Creighton SM. Chemical vaginitis: Implications and management.J Low Genit Tract Dis. 2013; 17: 95-8.

[2] Ugburo AO, Fadeyibi IO, Oluwole AA, Mofikoya BO, Gbadegesin A, Adegbola O, et al. The epidemiology and management of gynatresia in Lagos, southwest Nigeria. Int J Gynaecol Obstet. 2012; 118: 231-5.

[3] Arowojolu AO, Okunlola MA, Adekunle AO, et al. Three decades of acquired gynaetresia in Ibadan: clinical presentation and management. J Obstet Gynaecol. 2001; 21: 375-8.

[4] Okunola MA, Adekunle AO, Arowojolu AO. Management outcome in patients with acquired gynaetresia in Ibadan. Trop. J. Obstet Gynaecol. 2001; 18: 12-15.

[5] Unuigbe JA, Ojobo S, Oronsaye AU, The challenges of vaginal atresia and stenosis: Nigerian experience. Int J Gynaecol Obstet. 1984; 22:1-4.

[6] Park Y, Im E. Postpartum gynetresia. Perinatology. 2019; 30: 36-9.

[7] Anzaku SA, Ahmadu D, Mikah S, Didamson GD. Cryptomenorrhea due to acquired mid-vaginal atresia: A case report treated by vaginoplasty and serial vaginal dilatation. J Gynecol Infertility. 2017; 1: 1.

[8] Kaur G, Sinha M, Gupta R. Postpartum vaginal stenosis due to chemical vaginitis. J ClinDiagn Res: JCDR. 2016; 10: QD03.

[9] Adeniyi A0, Olaitan PB, Tijani A, Ayinde 0, Komolafe JO, Oboro VO. Acquired gynaetersia in Pregnancy: successful delivery and vaginoplasty. Trop. J. Obstet. Gynaecology. 2006; 23(2): 189-190. 
[10] Kunwar S, Khan T, Gupta H. Case report: Acquired gynatresia. BMJ Case Rep. 2014: bcr2014203529.

[11] Allen 00, Badejoko 00. Once treated, twice harmed: insertion of herbs. Tropical Journal of Obstetrics and Gynaecology. 2019; 36(3): 472-473.

[12] Umar AG, Ahmed Y, Garba JA, Adoke AU, Saidu AD, Hassan M. Successful pregnancy following acquired gynaetresia. Ann. Afr. Med. 2019; 18: 108-110.

[13] Gupta R, Bozzay JD, Williams DL, Depond RT, Gantt PA. Management of recurrent stricture formation after tranverse vaginal septum excision. Case Rep. Obstet Gynaecol. 2015; 97: 54-63. 